\title{
Raskausdiabetes - historiallisia ja ravitsemustieteellisiä näkökulmia
}

Raskauden aikana äidin sokeriaineenvaihdunta joutuu koetukselle. Yksinkertaistaen äidin elimistö vastustaa glukoosia. Tämän tarkoituksena on mahdollisesti ravinnon riittävä kulkeutuminen äidin sijaan kehittyvälle sikiölle. Yleensä haiman lisääntynyt insuliinin tuotanto kompensoi tilanteen, jolloin äidin verensokeri pysyy normaalina. Osalla naisista tämä ei toteudu, jolloin veren glukoosipitoisuus nousee tavallista korkeammaksi. Tilaa kutsutaan raskausdiabetekseksi. Raskausdiabetes määritellään glukoosiaineenvaihdunnan häiriöksi, joka todetaan ensimmäisen kerran raskauden aikana (1). Raskausdiabetes lisää riskiä sikiön liikakasvulle ja synnytyskomplikaatioille $(2,3)$. Yleensä sokeriaineenvaihdunta normalisoituu synnytyksen jälkeen, mutta sekä äidillä että lapsella on suurentunut riski myöhemmälle tyypin 2 diabetekselle (4). Raskausdiabetes koskettaa noin $15 \%$ suomalaisista synnyttäjistä (5).

Diabeteksesta raskauden aikana on ensimmäisiä merkintöjä 1800-luvun alusta (6). Tämä on noin 3000 vuotta myöhemmin kuin ensimmäiset merkinnät diabeteksesta eiraskaana olevilla. Diabetes raskauden aikana on ollut harvinaista, koska insuliininpuutosdiabetesta sairastavien elinaika on ollut lyhyt ja hedelmättö- myys heille tyypillistä. Tyypin 2 diabeteskaan ei ole ollut yleistä hedelmällisessä iässä olevien keskuudessa. Raskausdiabetes, sellaisena kuin sen nykyään ymmärrämme, on ollut luultavasti harvinaista vähäisemmän lihavuuden ja nuoremman lisääntymisiän takia. Lisäksi oireettomuuden takia lievää raskausdiabetesta ei ole tuolloin tunnettu.

Noista ensimmäisistä merkinnöistä 1800-luvulla ilmenee, että diabetesta raskauden aikana sairastavista äideistä noin puolet kuoli raskauden aikana tai 2 vuoden sisällä synnytyksestä (7). Sikiökuolemia esiintyi noin neljäsosasta puoleen raskauksista. Näihin lukuihin tosin sisältyivät sekä pysyvää diabetesta että raskausdiabetesta sairastavat äidit ja heidän lapsensa. Raskausdiabeetikoista lukuihin sisältyvät vain oireelliset tapaukset.

Nämä suuret kuolleisuusluvut muuttuivat insuliinin keksimisen myötä 1920-luvulla, jolloin etenkin äitien kuolleisuusluvut tippuivat. Uusien sikiön ja istukan tutkimusmenetelmien, sekä seulonnan myötä lapsikuolleisuus pieneni edelleen. Nykyään lähes jokainen raskaana oleva käy läpi sokerirasitustestin raskausdiabeteksen varalta. Hoidon nopeasta kehityksestä huolimatta raskausdiabetes aiheuttaa yhä synnytyskomplikaa- tioita, sekä lisääntynyttä riskiä äidin ja lapsen myöhemmälle tyypin 2 diabetekselle. Raskausdiabetesta ehkäisemällä voitaisiin mahdollisesti vaikuttaa sekä äidin että lapsen pitkäaikaiseen terveyteen sekä säästää yhteiskunnan terveysmenoissa. Raskausdiabeteksen ehkäisy onkin ollut viime vuosina tutkimuksen keskiössä.

Riskitekijöitä raskausdiabetekselle ovat äidin korkea ikä, korkea painoindeksi ennen raskautta, suuri aikaisempien synnytysten lukumäärä, sukurasitus, ja aikaisempi raskausdiabetes (8). Seurantatutkimusten perusteella myös epäterveelliset elämäntavat kuten epäterveellinen ruokavalio ja liikkumattomuus ovat riskitekijöitä (9).

Tiedämme, että tyypin 2 diabetesta voidaan ehkäistä elämäntapamuutoksin (10). Riski pienenee liikuntaa lisäämällä, ruokavaliomuutoksilla ja laihduttamalla. Koska raskausdiabeteksen mekanismit ovat samansuuntaiset kuin tyypin 2 diabeteksen, on elämäntapaneuvonnan toivottu tehoavan myös raskausdiabetesta ehkäisevästi. Suuri osa lukuisista elämäntapainterventiotutkimuksista raskausdiabeteksen ehkäisemiseksi on kuitenkin epäonnistunut (11). Tämä on herättänyt epäilyksen, että muutokset raskauden aikana ovat liian myöhässä ehkäisemään 
raskausdiabetesta. Näin voi olla, mutta en kuitenkaan olisi hätäinen johtopäätöksissä. Tähänastisissa elämäntapaneuvontatutkimuksissa on joitain merkittäviä heikkouksia. Tärkeimpiä heikkouksia ovat pienet tutkimusjoukot, glukoosinsiedon alkumittauksen puuttuminen ja puuttuvat mittaukset elämäntapojen todellisista muutoksista. On myös mahdollista, että tutkimuksissa toteutettu elämäntapaohjaus alkuraskaudesta lähtien ei ole tarpeeksi intensiivistä pienentämään riskiä niin lyhyessä ajassa.

Pitkittäisten havaintotutkimusten perusteella raskausdiabeteksen riskiä pienentävät muun muassa sellaiset ruokavaliot kuin Välimeren ruokavalio, amerikkalaisten ravitsemussuositusten mukainen ruokavalio sekä alhaisen glykeemisen indeksin ruokavalio (12). Näillä ruokavalioilla on yhdistäviä tekijöitä: niihin kuuluu runsaasti kasviksia ja hedelmiä, täysjyväviljatuotteita, ja kasvirasvaa, sekä vähän punaista lihaa, pitkälle jalostettuja viljatuotteita, ja sokeroituja juomia. Nämä ovat keskeinen sanoma myös Pohjoismaisissa ravitsemussuosituksissa.

Toisin kuin intuitio ehkä sanoisi, vähähiilihydraattinen ruokavalio ei näytä pienentävän raskausdiabeteksen riskiä, vaan tutkimusten mukaan vähähiilihydraattinen ruokavalio voi olla yhteydessä jopa suurempaan raskausdiabeteksen riskiin (13). Tämä tosin vain silloin kun rasva ja proteiini tulevat eläinkunnan tuotteista. Jos rasva ja proteiini saadaan kasvikunnan tuotteista, vähähiilihydraattisella ruokavaliol- la ei ole yhteyttä raskausdiabeteksen syntyyn.

Olet saattanut huomata, että en ole juurikaan puhunut ravintoaineista vaan ruokavalioista. Ravitsemustutkimuksessa voidaan keskittyä yksittäisiin ravintoaineisiin ja niiden terveysvaikutuksiin. Tässä lähestymistavassa on kuitenkin ongelmia. Emme nimittäin syö yksittäisiä ravintoaineita vaan ruokien yhdistelmiä eli ruokavalioita. Ravintoaineilla voi olla elimistössä yhdysvaikutuksia, jotka jätämme kokonaan huomiotta tutkiessamme yksittäisiä ravintoaineita. Usein ravintoaineiden saantien välillä on korrelaatio, jolloin emme oikeastaan voi tietää onko tulos seurausta tutkimastamme ravintoaineesta vai kenties toisesta ravintoaineesta, jolla on sama saantilähde.

Muun muassa näistä syistä tutkimme yhä useammin kokonaisruokavalioita (14). Kokonaisruokavaliota voidaan tutkia esimerkiksi muodostamalla pisteytysjärjestelmä, jossa ruokavalion eri osatekijöistä annetaan tietty määrä pisteitä. Nämä pisteet lasketaan yhteen yhdeksi luvuksi, joka kuvaa ruokavalion laatua suhteessa esimerkiksi ravitsemussuosituksiin. Esimerkiksi korkeat pisteet Välimeren ruokavalioindeksistä kertovat ruokavalion vastaavan paremmin Välimeren ruokavaliota kuin matalammat pisteet. Indekseillä on tutkittu esimerkiksi Välimeren tai Itämeren ruokavalion yhteyttä terveyteen.

Yhtenä väitöskirjani osatyönä oli tällaisen ruokavalioindeksin kehittäminen ja luotettavuuden eli validiteetin ja reliabiliteetin tutkiminen (15).
Indeksin oli tarkoitus mitata kuinka hyvin ruokavalio vastasi Pohjoismaisten ravitsemussuositusten mukaista ruokavaliota. Totesimme, että indeksi toimii kohtuullisesti. Käytimme kyseistä indeksiä tutkiessamme suuressa raskausdiabeteksen riskissä olevien odottavien naisten ruokavaliota ja sen yhteyttä raskausdiabetekseen. Tärkein löytö oli, että ruokavalion muuttaminen kohti Pohjoismaisia ravitsemussuosituksia ensimmäisen ja toisen raskauskolmanneksen välillä on yhteydessä pienentyneeseen raskausdiabeteksen riskiin (16). Tämä tapahtui painosta tai sen muutoksesta riippumatta. Tämä on tärkeä löytö, koska se viittaa siihen, että ruokavaliomuutos raskauden aikana ei ole liian myöhässä ehkäisemään raskausdiabeteksen syntyä.

Havaintotutkimuksella ei kuitenkaan pystytä aukottomasti päättelemään syy-seuraussuhdetta. Siihen tarvitaan satunnaistettu kontrolloitu interventiotutkimus. Kuten aikaisemmin mainitsin, useat tällaiset interventiotutkimukset ovat epäonnistuneet. Päätelmiä tehdessä tulee kuitenkin muistaa tutkimusten heikkoudet. Lisäksi olemme huomanneet, että raskausdiabetes näyttäisi jakautuvan mekanismeiltaan useampaan alaryhmään. Osa sairastuu, vaikka tiedossa olevia riskitekijöitä ei olisi emmekä tällä hetkellä tiedä miksi. Näihin tekijöihin, sekä väitöskirjani tuloksiin perustuen totean, että raskausdiabeteksen ehkäisytutkimusta elämäntapamuutoksin tulee jatkaa ja pyrkiä löytämään ne ryhmät, jotka siitä voivat 
hyötyä. Koska aikainen interventio todennäköisesti lisäisi onnistumisen mahdollisuutta, raskautta suunnitteleville perheille tulisi suunnata tietoa raskautta edeltävien elintapojen merkityksestä sekä vanhemmille että tulevalle lapselle. Raskausdiabeteksen ollessa yleisempää alhaisemmissa sosioekonomisissa luokissa, äitiysneuvola- järjestelmään upotettu tehostettu elintapaneuvonta voisi myös kaventaa eri sosioekonomisten luokkien välisiä terveyseroja.

\section{LÄHTEET:}

(1) International Association of Diabetes and Pregnancy Study Groups Consensus Panel, Metzger BE, Gabbe SG, Persson B, Buchanan TA, Catalano PA, et al. International association of diabetes and pregnancy study groups recommendations on the diagnosis and classification of hyperglycemia in pregnancy. Diabetes Care 2010;33:676682. doi: $10.2337 / \mathrm{dc} 09-1848$ https://doi.org/10.2337/dc091848

(2) Catalano PM, McIntyre HD, Cruickshank JK, ym. The hyperglycemia and adverse pregnancy outcome study: associations of GDM and obesity with pregnancy outcomes. Diabetes Care 2012;35:780-786. doi: $10.2337 / \mathrm{dc} 11-1790$ https://doi.org/10.2337/dc111790

(3) Farrar D, Simmonds M, Bryant M, ym. Hyperglycaemia and risk of adverse perinatal outcomes: systematic review and meta-analysis. BMJ 2016;354:i4694. doi: 10.1136/bmj.i4694 https://doi.org/10.1136/bmj. i4694

(4) Kim C, Newton KM, Knopp RH. Gestational diabetes and the incidence of type 2 diabetes: a systematic review. Diabetes Care 2002;25:18621868. https://doi.org/10.2337/ diacare.25.10.1862

(5) Terveyden ja hyvinvoinnin laitos. Perinataalitilasto synnyttäjät, synnytykset ja vastasyntyneet 2014 . THL 2015. Luettu 13.8.2017. http://urn.fi/URN:NBN:fife2016101024921

(6) Mestman JH. Historical
Notes on Diabetes and Pregnancy. The Endocrinologist 2002;12:224242.

https://doi.org/10.1097 /00019616-200205000-00010

(7) Hare JW, White P. Pregnancy in diabetes complicated by vascular disease. Diabetes 1977;26:953-955. https://doi. org/10.2337/diab.26.10.953. https://doi.org/10.2337/ diab.26.10.953

(8) Cypryk K, Szymczak W, Czupryniak L, ym. Gestational diabetes mellitus - an analysis of risk factors. Endokrynol Pol 2008;59:393397.

(9) Zhang C, Ning Y. Effect of dietary and lifestyle factors on the risk of gestational diabetes: review of epidemiologic evidence. Am J Clin Nutr 2011;94:1975S-1979S. doi: 10.3945/ajen.110.001032 https://doi.org/10.3945/ ajcn.110.001032

(10) Tuomilehto J, Lindstrom J, Eriksson JG, ym. Prevention of type 2 diabetes mellitus by changes in lifestyle among subjects with impaired glucose tolerance. N Engl J Med 2001;344:13431350. doi: 10.1056/ NEJM200105033441801 https://doi.org/10.1056/ NEJM200105033441801

(11) Bain E, Crane M, Tieu $\mathrm{J}, \mathrm{ym}$. Diet and exercise interventions for preventing gestational diabetes mellitus. Cochrane Database of Systematic Reviews 2015;4:CD010443. doi: $10.1002 / 14651858$. CD010443.pub2 https://doi.org/10.1002/ 14651858.CD010443.pub2

(12) Tobias DK, Zhang C, Chavarro J, ym. Prepregnancy adherence to dietary patterns and lower risk of gestational diabetes mellitus. Am J Clin Nutr 2012;96:289-295. doi: 10.3945/ajen.111.028266 https://doi.org/10.3945/ ajcn.111.028266

(13) Bao W, Bowers K, Tobias DK, ym. Prepregnancy low-carbohydrate dietary pattern and risk of gestational diabetes mellitus: a prospective cohort study. Am J Clin Nutr 2014;99:1378-

1384. doi: $10.3945 /$ ajcn.113.082966 https:/doi.org/10.3945/ ajcn.113.082966

(14) Waijers PM, Feskens EJ, Ocke MC. A critical review of predefined diet quality scores. Br J Nutr 2007;97:219231. doi: 10.1017/ S0007114507250421 https://doi.org/10.1017/ S0007114507250421

(15) Meinila J, Valkama A, Koivusalo SB, ym. Healthy Food Intake Index (HFII) Validity and reproducibility in a gestational-diabetes-risk population. BMC Public Health 2016;16:680. doi: 10.1186/s12889-016-3303-7 https://doi.org/10.1186/ s12889-016-3303-7

(16) Meinila J, Valkama A, Koivusalo SB, ym. Is improvement in the Healthy Food Intake Index (HFII) related to a lower risk for gestational diabetes? $\mathrm{Br}$ J Nutr 2017;117:11031109. doi: $10.1017 /$ S0007114517001015 https://doi.org/10.1017/ S0007114517001015

Jelena Meinilä

FT, tutkija

Helsingin yliopisto

Helsingin ja Uudenmaan sairaanhoitopiiri 